CIHM

Microfiche

Series

(Monographs)
ICMH

Collection de microfiches (monographies)

Canacian institute for Historical Microroproductions / Institut canadien de microreproductions historiques
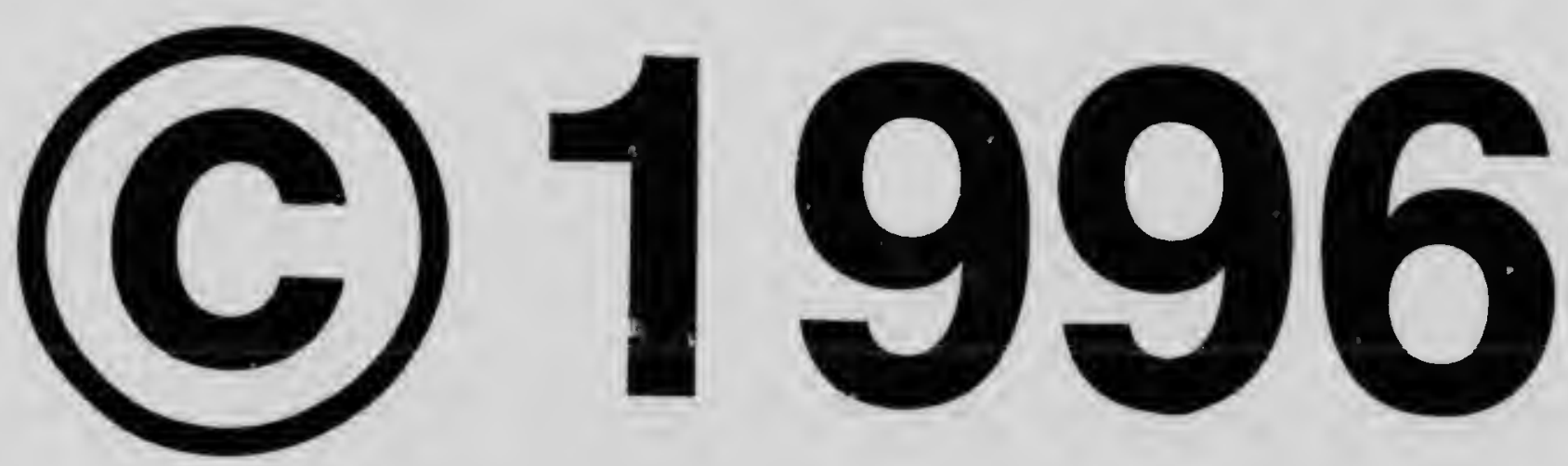


\section{Technical and Bibliographic Notes / Notes technique et bibliographiques}

The Institute has attempted to obtain the best original copy available for filming. Features of this copy which may be bibliographically unique, which may alter any of the images in the reproduction, or which may significantly change the usual method of filming are checked below.

\section{Coloured covers I}

Couverture de couleur

Covers damaged /

Couverture endommagée

Covers restored and/or laminated /

Couverture restaurée et/ou pelliculée

Cover title missing / Le titre de couverture manque

Coloured maps / Cartes géographiques en couleur

Coloured ink (i.e. other than blue or black) /

Encre de couleur (i.e. autre que bleue ou noire)

Coloured plates and/or illustrations /

Planches etlou illustrations en couleur

Bound with other material /

Relié avec d'autres documents

Only edition available /

Seule édition disponible

Tight binding may cause shadows or distortion along interior margin / La reliure serrée peut causer de l'ombre ou de la distorsion le long de la marge inténeure.

Blank leaves added during restorations may appear within the text. Whenever possible, these have been omitted from filming / II se peut que certaines pages blanches ajoutées lors d'une restauration apparaissent dans le texte, mais, lorsque cela était possible, ces pages n'ont pas été filmées.
L'Institut a microfilmé le meilleur examplaire qu'il lui a été possible de se procurer. Les détails de cet exempiaire qui sont peut-être uniques du point de vue bibliographique, qui peuvent modifier une image reproduite, ou qui peuvent exiger une modifications dans la méthode normale de filmage sont indiqués ci-dessous.

\section{Coloured pages / Pages de couleur}

Pages damaged / Pages endommagies

Fages restored and/or laminated /

Pages restaurées etou pelliculées

Pages discoloured, stained or foxed /

Pages décolorées, tachetées ou piquées

Pages detached / Pages détachées

Showthrough / Transparence

Quality of frint varies /

Qualité inégale de l'impression

Includes supplementary material /

Comprend dı matériel sııplémentaire

Pages wholly or partially obscured by errata slips, tissues, etc., have been refilmed to ensure the best possible image / Les pages totalement ou partiellement obscurcies par un feuillet d'errata, une pelure, etc., ont été filmées à nouveau de façon à obtenir la meilleure image possible.

Opposing pages with varying colouration or discolourations are filmed twice to ensure the best possible image / Les pages s'opposant ayant des colorations variables ou des décolorations sont filmées deux fois afin d'obtenir la meilleur image possible.

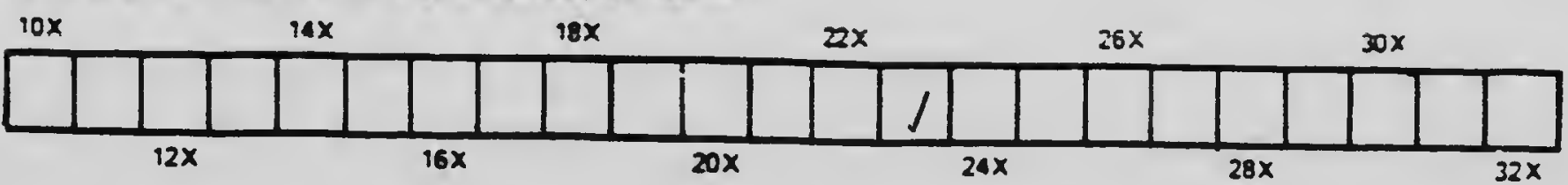


The copy fllmed here has been reproduced thenks to the generoslty of:

Harriet Irving Library

Univereity of Now Brunswick

The Images appearing here are the best quality possible considerlng the condition end leglblllty of the original copy and In keeplng with the filming contract specifications.

Original copies in printed paper covers are filmed beginning with the front cover and ending on the last page with a printed or lllustrated Impression, or the back cover when approprlate. All other original coples are fllmed beginning on the flrst page with a printed or illustrated impression, and ending on the last page with a printed or illustrated impression.

The last recorded frame on each microfiche shall contain the symbol $\rightarrow$ Imeaning "CONTINUED"), or the symbol $\nabla$ (meaning "END"), whichever applies.

Maps, plates, charts, etc., may be filmed at different reduction ratios. Those too large to be entlrely included in one exposure are filmed beginning in the upper left hand corner, left to right and top to bottom, as many frames as required. The following dlagrams illustrate the method:
L'exemplaire fllmb fut reprodult grâce to lo gónórosité de:

$$
\begin{aligned}
& \text { Harriet Irving Llbrary } \\
& \text { University of New Brunswick }
\end{aligned}
$$

Les Images sulvantes ont bté reprodultes ovec le plus grand soln, compte tenu de la conditlon et de la netteté de l'oxemplaire filmó, ot en conformité avec les conditlons du contrat de fllmage.

Les exemplalres orlginaux dont la couverture on popler est Imprimbe sont filmós en commençant par le premler plat ot en terminant solt par la derniere page qul comporte une emprelnte d'Impresslon ou d'lliustration, soit par le second plat, selon le cas. Tous les autres exemplalres orlginaux sont filmós en commencant par la premlère page qul comporte une empreinte d'impresslon ou d'illustration et en torminant par la derniere page qui comporte une telle empreinte.

Un des symboles sulvants apparaîtra sur la derniere image de chaque microfiche, selon le cas: le symbole $\rightarrow$ slgnifie "A SUIVRE". le symbole $\nabla$ signifie "FIN".

Les cartes, planclies, tableaux, etc., peuvent stro filmb́s à des taux de réduction différents. Lorsque le document est trop grand pour etre reproduit on un seul clich6. II est filmb a pertir de i'angle supórleur gauche, de gauche a droit:!, ot de haut en bas, en prenant lo nombre d'images nócessalre. Les diagrammes sulvants Illustrent la mothode.

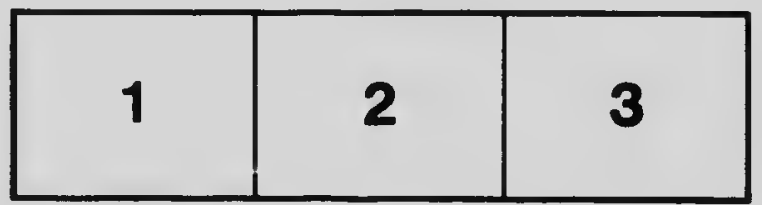

\begin{tabular}{|l|l|l|}
\hline 1 & 2 & 3 \\
\hline 4 & 5 & 6 \\
\hline
\end{tabular}

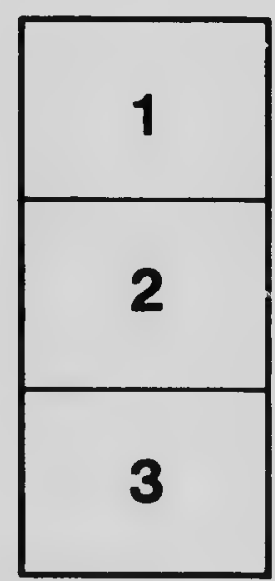




\section{MICROCOPY RESOLUTION TEST CHART}

(ANSI and ISO TEST CMART NO. 2)
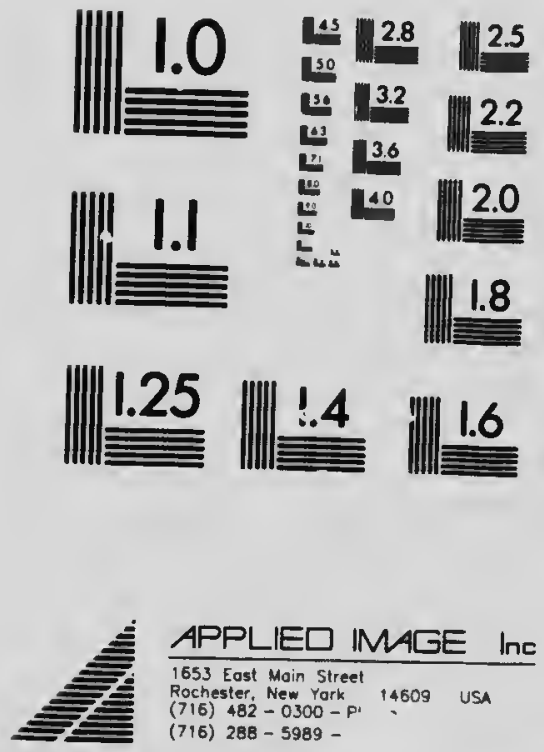
FROM THE TRANSACTIONS OF THE ROYAL SOCIETY OF CANADA SECOND SERIES-1905-1906

VOLUME XI

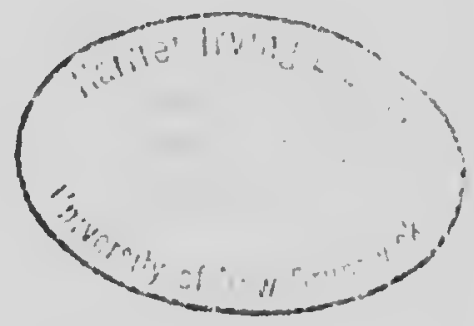

\title{
Report of the Botanical Club of Canada for $1904-1905$
}

\author{
By A. H. MacKAY, LL.D., \\ General Secretary
}

(ISSUED JULY, 1905)

POR SALE BY

J. HOPE \& SONS, OTTAWA; THE COPF-CLARK CD., TORONTO BERNARD QUARITCH, LONDON, ENGLAND 


\title{
Report of the Botanical Club of Canada for 1904-1905
}

\author{
By A. H. MacKAY, LL.D. \\ General Secretary
}

ISSUED JULY, 1905 


\section{$-2-$

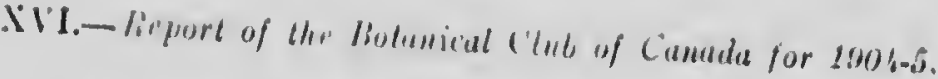

By the Generul Secretary, A. H. MAcKAY, LIJ.L

There was nothing striking in the history of the Chnb dus ang the

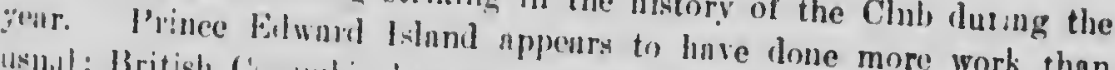
usulul; British (' anbia has not repurted as Inuch no usua In than Seotin the public schools linve herent loing and

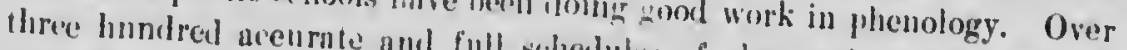
from as many school sortions schedult's of observations were sent in These were referrerl in representing crery county in the Province. cxnmination, selcetion, aromps to the following phenologienl staff for observations were pon, am compilution: ant the eriticisus on faulty

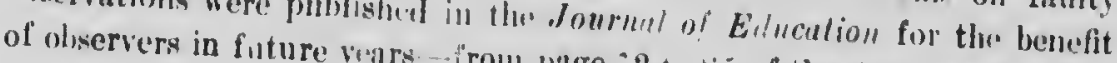

liegion 1. ( s amouth it Dighy), A. W. Horner, Principal, Salem Sehool, Yarmouth.

" II. (Sliclburne Co.), 1. Staulcy Bruce, P'rincipal, Acalleny, Sholburnc.

II. (Queen Co.), Miss .I. C. Hewitt, Scienee Tcacher, Aealciny, lunenburg.

11. (1.menburg ('o.), B. Melittrick, B.A., Prineipal, Academy, hinenburg.

III. (Ann. is Kings), li. Kobinson, Prineipal, Aeademy, Kentville.

IV. (llants (o.), Miss A. Forlies, B.A., Acadenıy, Windsor.

V. (Ialifax Co.), G. R. Marshall, B.A., Prineipal, C.A. School, Halifax.

V. (Guvshoro ('o.), J. B. MeCarthy, B.Šc., Science 'Laster, Academy, Halifax.

II. (Col. \& Cum.), J. l\%. Rarteaux, Science Master, Academy, Truro. "VIJ. (N. Cum. Co.), E. J. Lay, Principal, Acadeny,
Amhersi.

" VII. (P'ieton ('o.). IT. P. Fraser, Science Master, Acndemy, Picton.

" VII. (Antigonish Co.), F. G. Morehouse, Prineipal, Schools, Antigonish.

VIII. (Riehmond Co.). G. W. MacKienzie, B.A., Principal, Publie Schools, Sydney Mines.

"VIII., IX., X. (C.B.. Vic., \& Inv. Co.), I. A. DeWolf, M.Sc., High School, North Sydney. 
Thr phenochrons of ench of thuse compilers were unin avemund

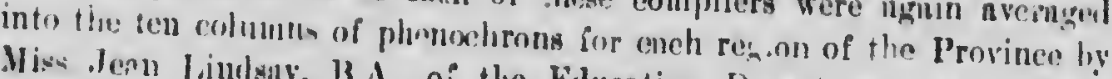
Miss den lindsay, 13.4, of the Filueation Depnetument, ns they re given in the first table following.

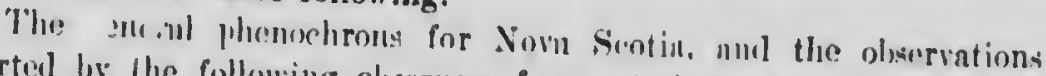
reported lye the following olververs from stutions within tho other Proviu es of the Deminion are given in the last table:

New Brunswick: Geo. V. Ilar. D.Sc., snint John.

P'rinee Blwarl lalaul: John IIncSwain, ('luerontetown.

Prince Bulwarl Islaul: J. .. Wuncus, Kensington.

Onturio: ('ephtis Ginillet, I'h.D., Ottuwa.

(Intariu: .Irs. F. E. Welster, Creculore.

Onturio: .1. B. Klught. (iumlph.

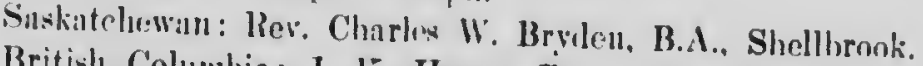

British Colımbin: J. K. Henry, $\dot{P}$ A., Vuncouver.

If was found to be imposible hitherto to nlotinin reports from lanken and Sewfonndlaul. Screnul parties at the heriuning of the vear hoped to be able to record olsservations, bitt before the close of the senson

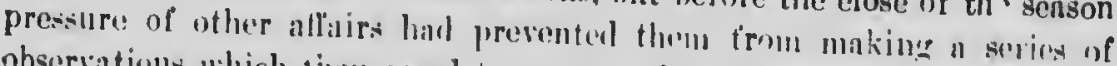
observations which iley cared to r port. Bat were only a half al lozen observatinus mate, thoy would be of very great intorest, for they wnatd form a hasis of enmlarison witl as many objents observel in the otner provinces. It is hoped we may he more sucessaful in the future in obtaining obserintions representing portions of the continent fom the Athantic to the Pneifie and north to the Irotic. Even shonld the obscrintions be very few, they would he of very great value.

Circular aud spocial latters wros sent out to hundreds of mitresses during the year, asking foi conperition in tiv. varions kinds of hatanical work which una be found convenient in earh incality. The exploration of the local floras is going stealily on. It is suiggested, thant those sending in to the ricneral sicretary list of plants new to any locality. should hnv each species with the notes on it wn separated on the manilscript. "'at auch :an he easily ent off' to be collated by the central $\mathrm{e} \cdot \mathrm{m}$ piler with similar noies on the same species from nther localitics.

The annus meeting of the Chub was held during the mecting of the Roval Socicty at Ottawa; the first meeting at noon on the 24th of May, 190:, and the second on the 25th May, at 4 p.m., in the Sectinn IV. meetiug room in the Ninr nal Sehool Building. There were present: John Mreoun, G. U. Hay, James Fleteher. Professor Fowler, Dr. Burgess, Mr. Evans, end A. H. MneKay. John 'faconn gare nn ilea of the amount of new work done since the first volume of the Catalogue 
of Comation lohnts was issund, and expressed the view that the revision

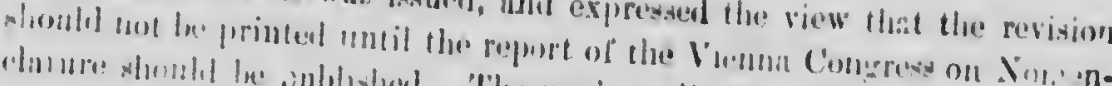

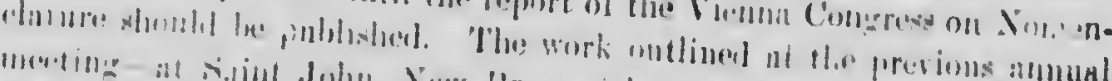

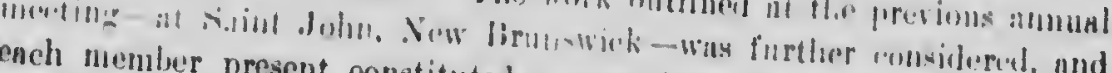
ench member present eonstituted at enmmittere (1) stimulato

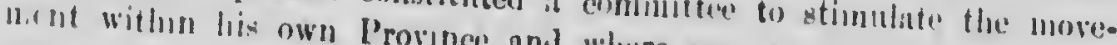
olfur. The ollicurs of the previl where ever na opportunity shoubl

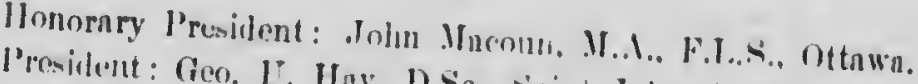

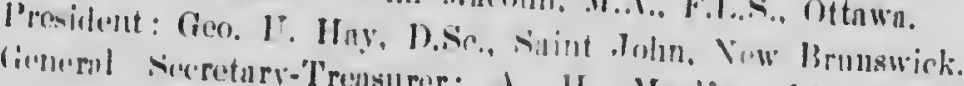
Novin sotin.

$$
\text { Secretaries for the I'rocines: }
$$

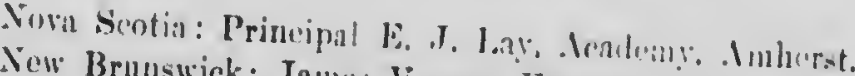

New Brunswick: James Vroom. Vist., St. Strphnon.

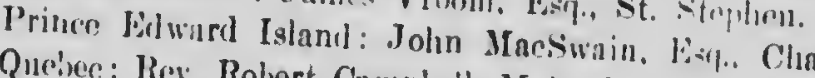

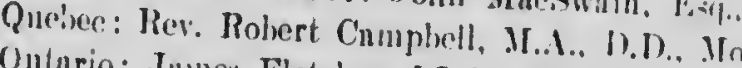

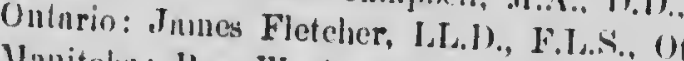

Janitolul Hev. IV. A. Burman, B.D., It

Thos B. D., llimipeg.

Tos. R. Donnelly, Pheasant Forks.

Alherta: Perey B. Gregritories: T. X. Willing. Esq., Reginn.

Saskntehewn. Bregson, lisı. Blackfalds.

British Coluter. C. W. Brylen, B.A.. Shellironk.

Vaneourer

The determinntion of species ean be most effectively male by

$$
\text { James M. Macones, }
$$

Curator of the Horbnium. Geolosical sureey.

\section{OTT.IW. ONT.}

The Botanical Chub of Canada was organized by a commitiee of section four of the Roral Socicty of Canada, at its meeting in Montreal,
May 29th, 18.1.

The object is to promote $b y$ coneerted local efforts and otherwise, the exploration of the fle sa of crery portion of British Ameriea, to publish complete lists of the sane in loeal papers as the work goes on, to have these lists colle ted nnd earefully examined in order to arrive at a correct knowiedge of the precise clinracter of our flora and its 


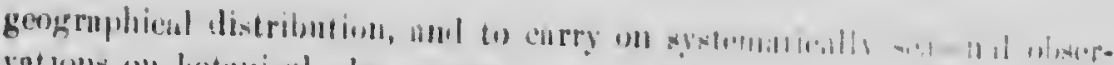

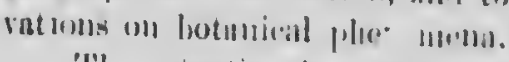

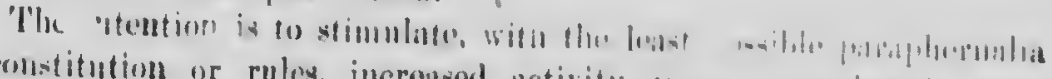

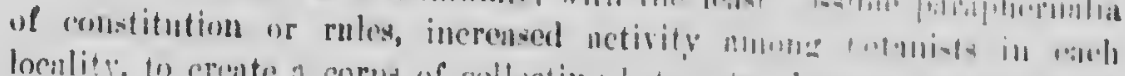

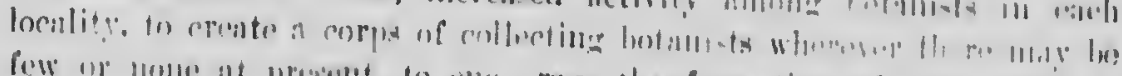

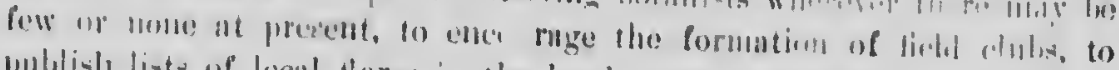

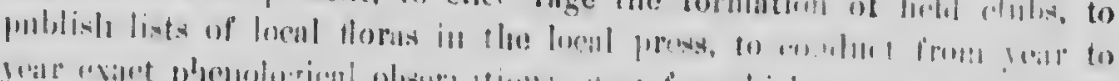

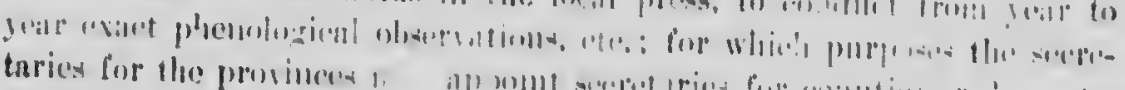

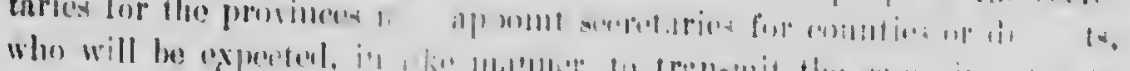

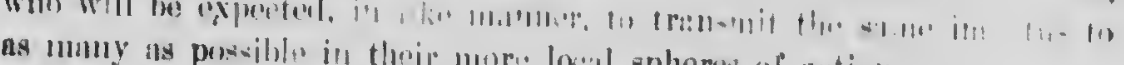

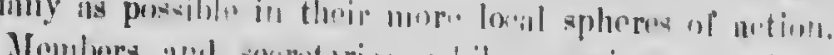

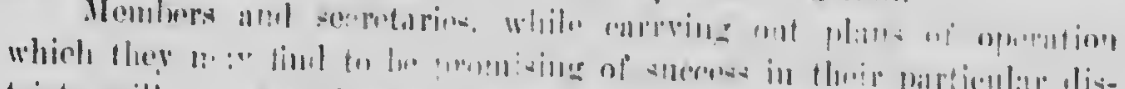

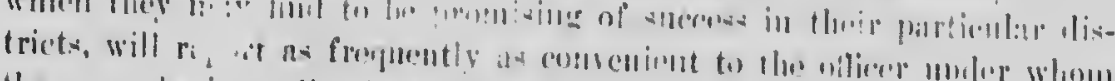
they ma!y lo immealinfoly actimg.

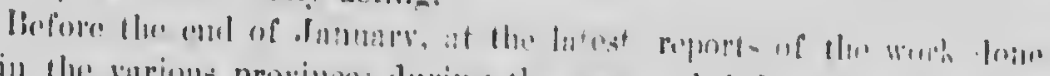

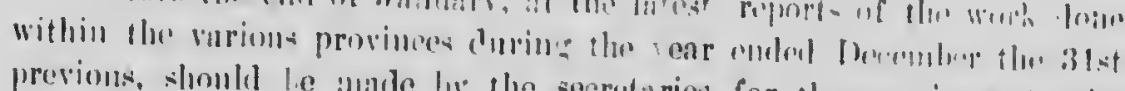

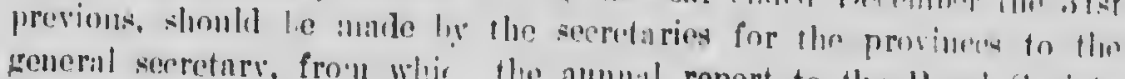

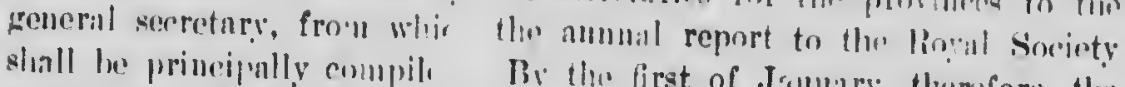

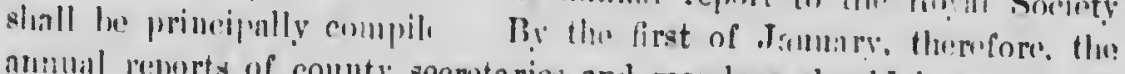
allibal reports of eomuty secretaries and members should be sent in to the seredaries of the ponviness.

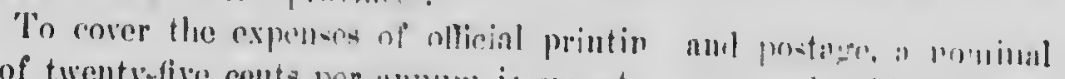

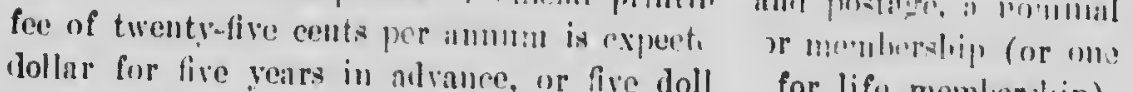
Secretarios for the provieses or fifo monlorship).

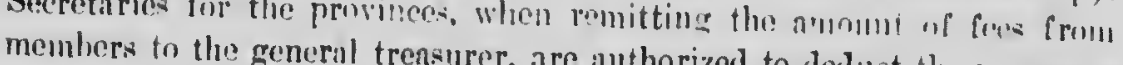

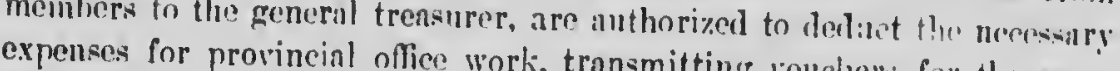
with the bolntice.

The manes of those reportine any lind of valumble botanical work during the pear will he published in the list of activ members, mon should the parment of fees be forgotten. All payments aro credited to the enrent year and the future. Iapsed netive membership can, therefore, be restored at any tine without the payment of arrears. 


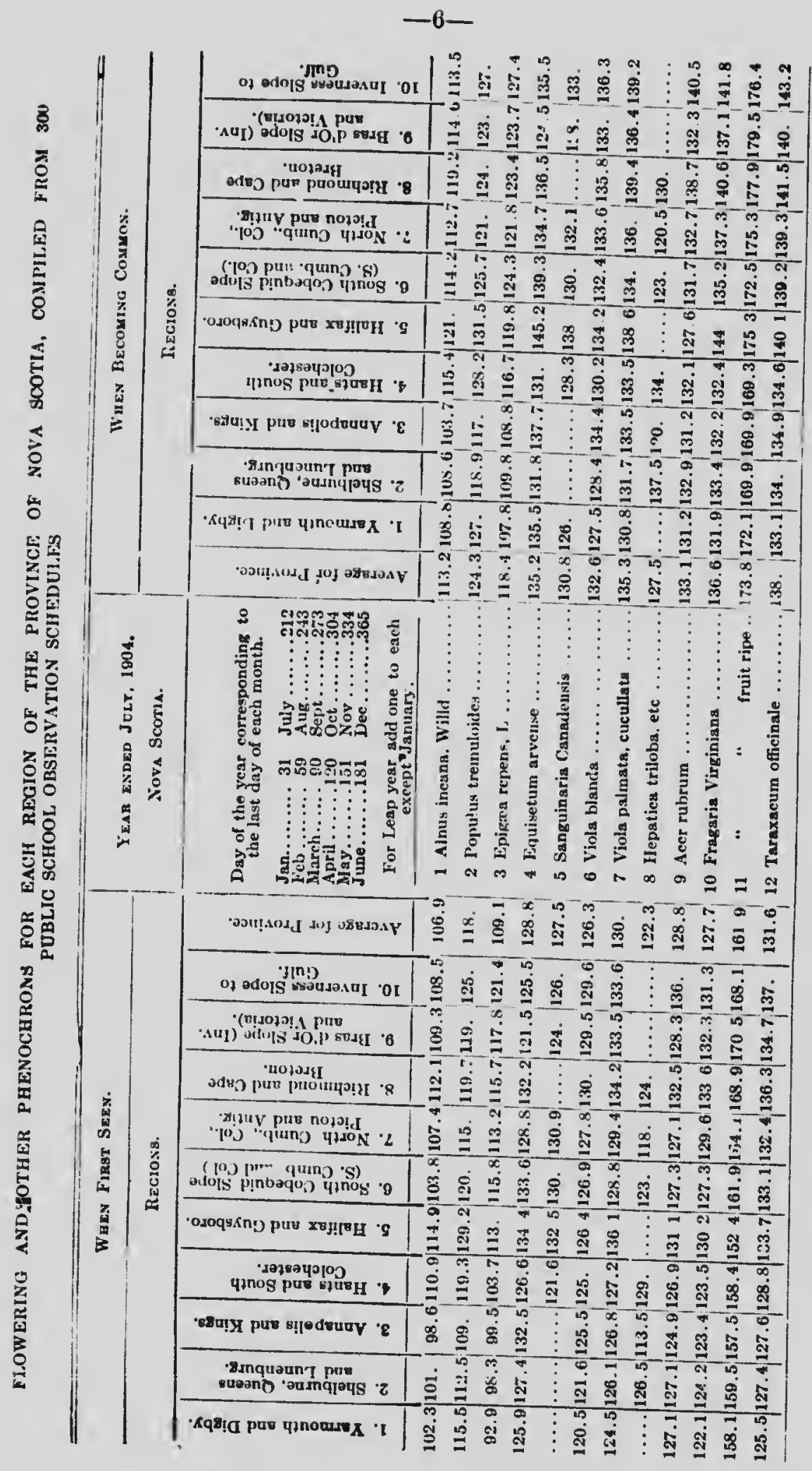




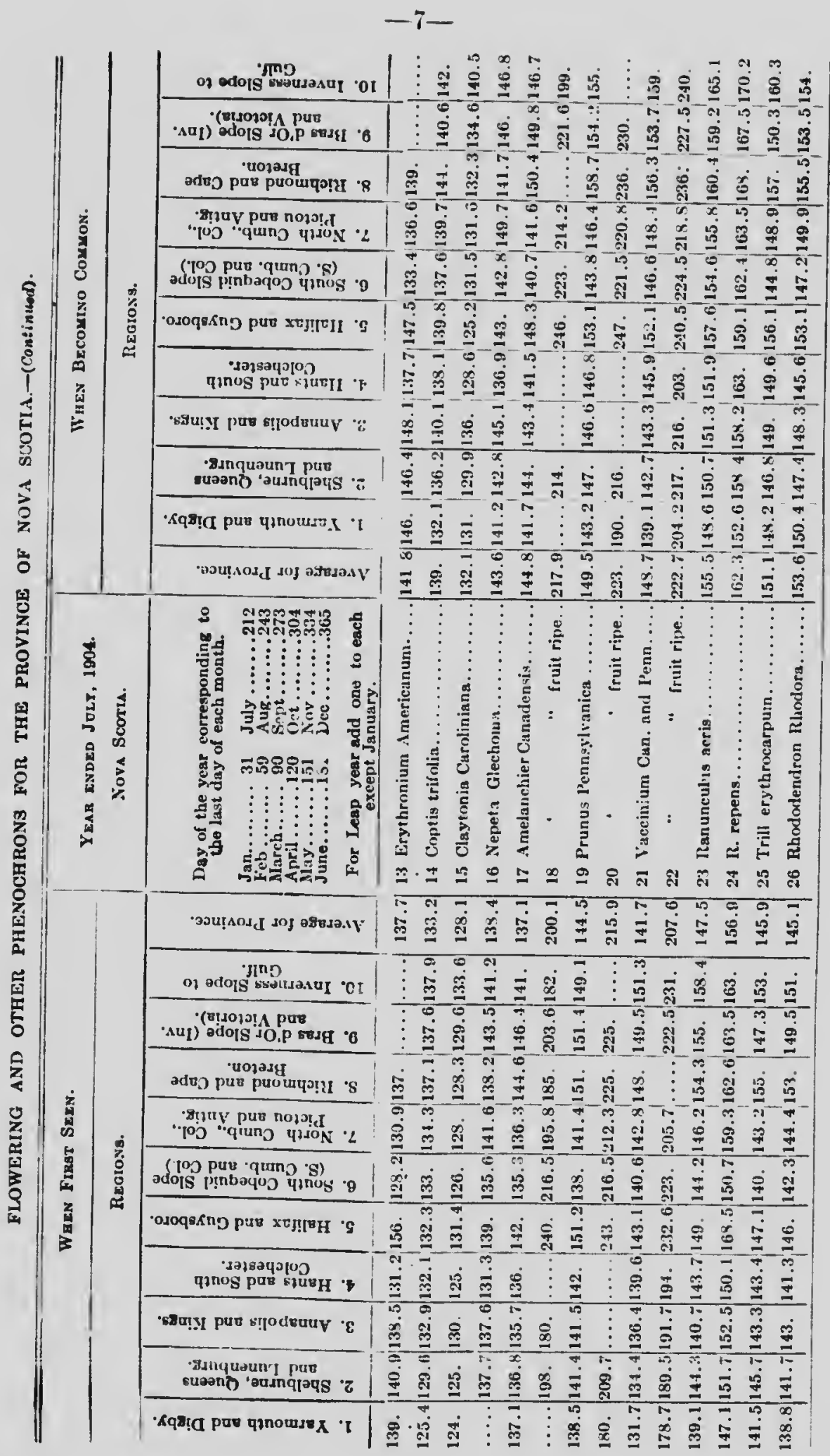




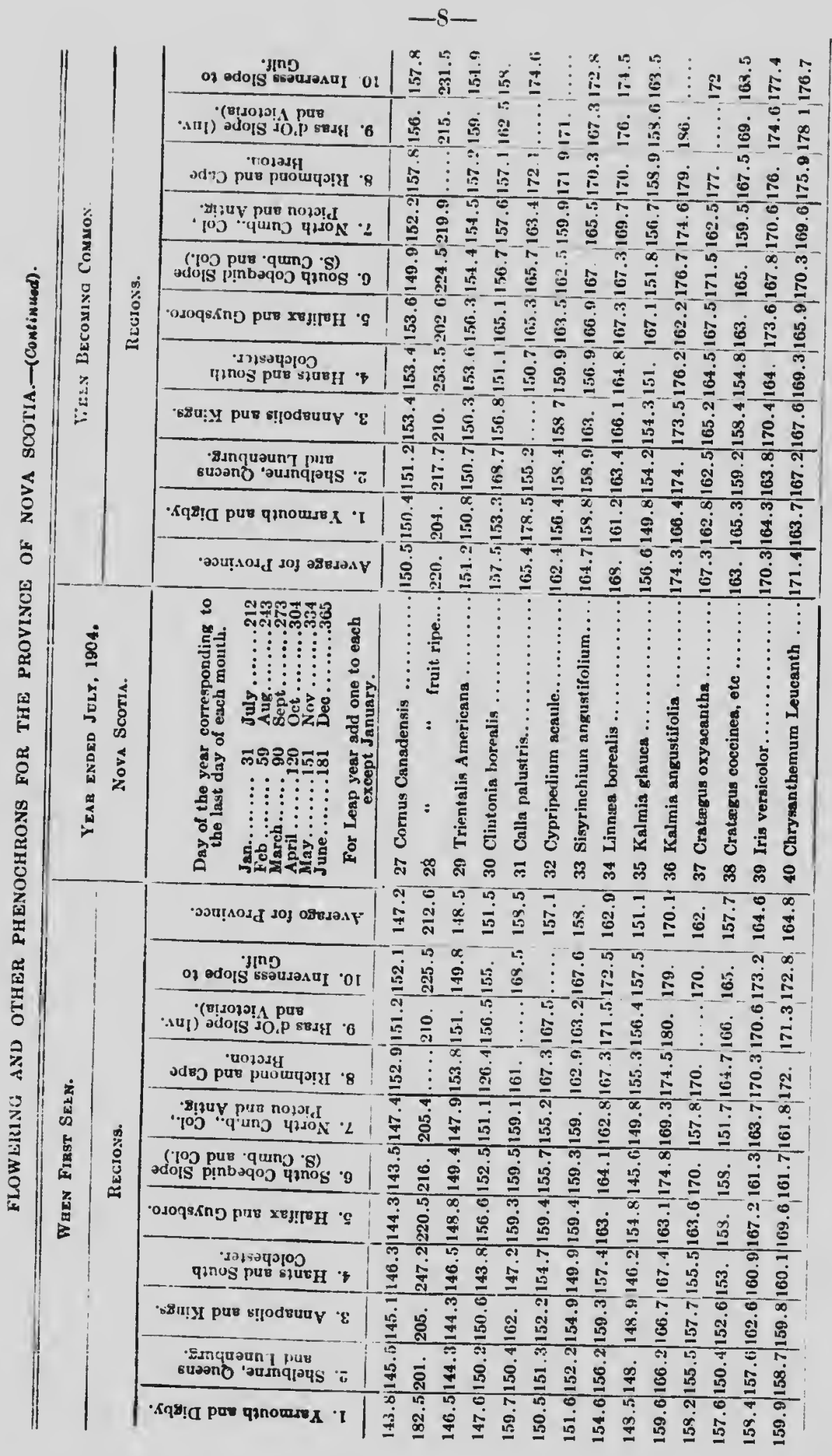




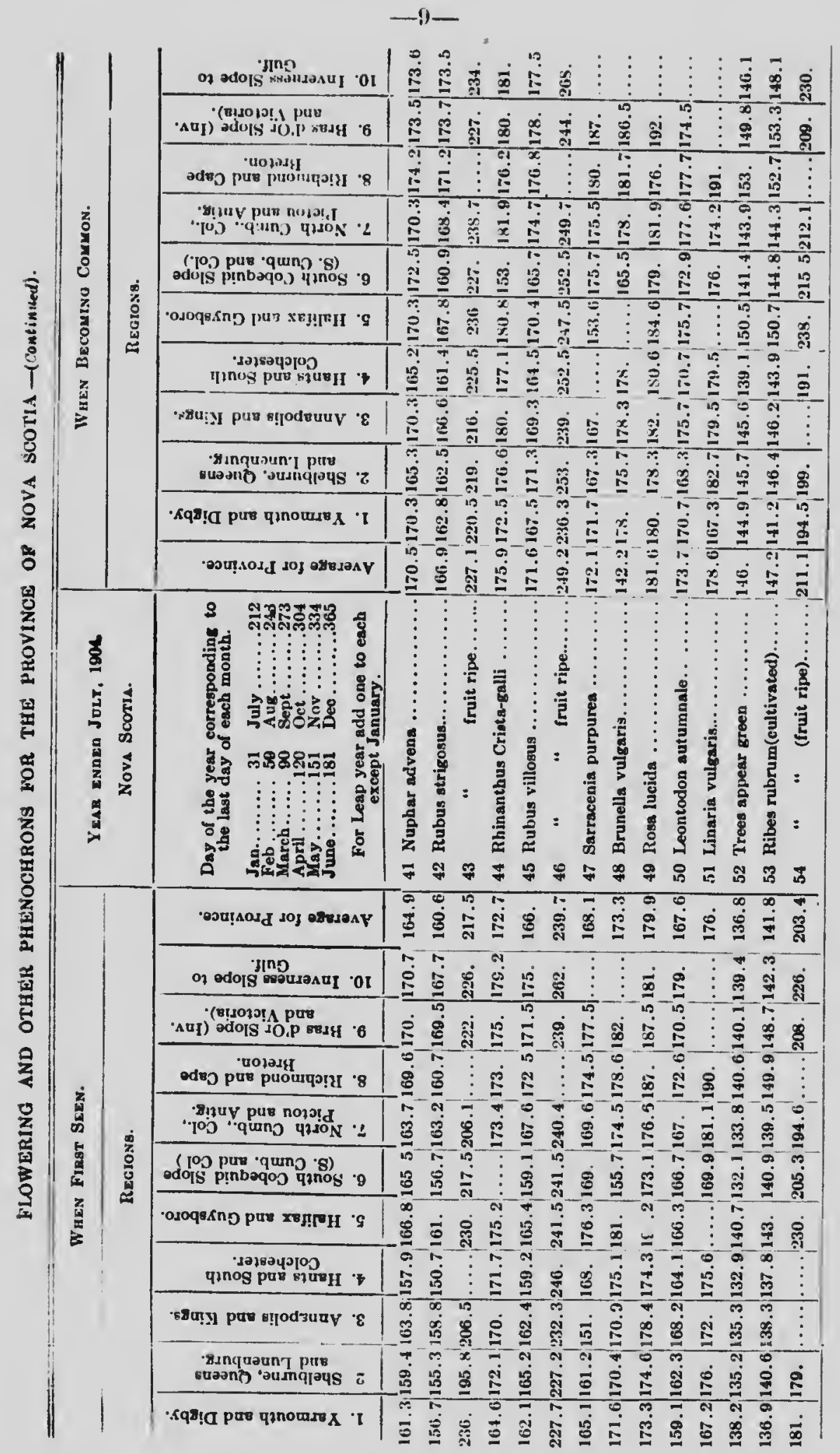




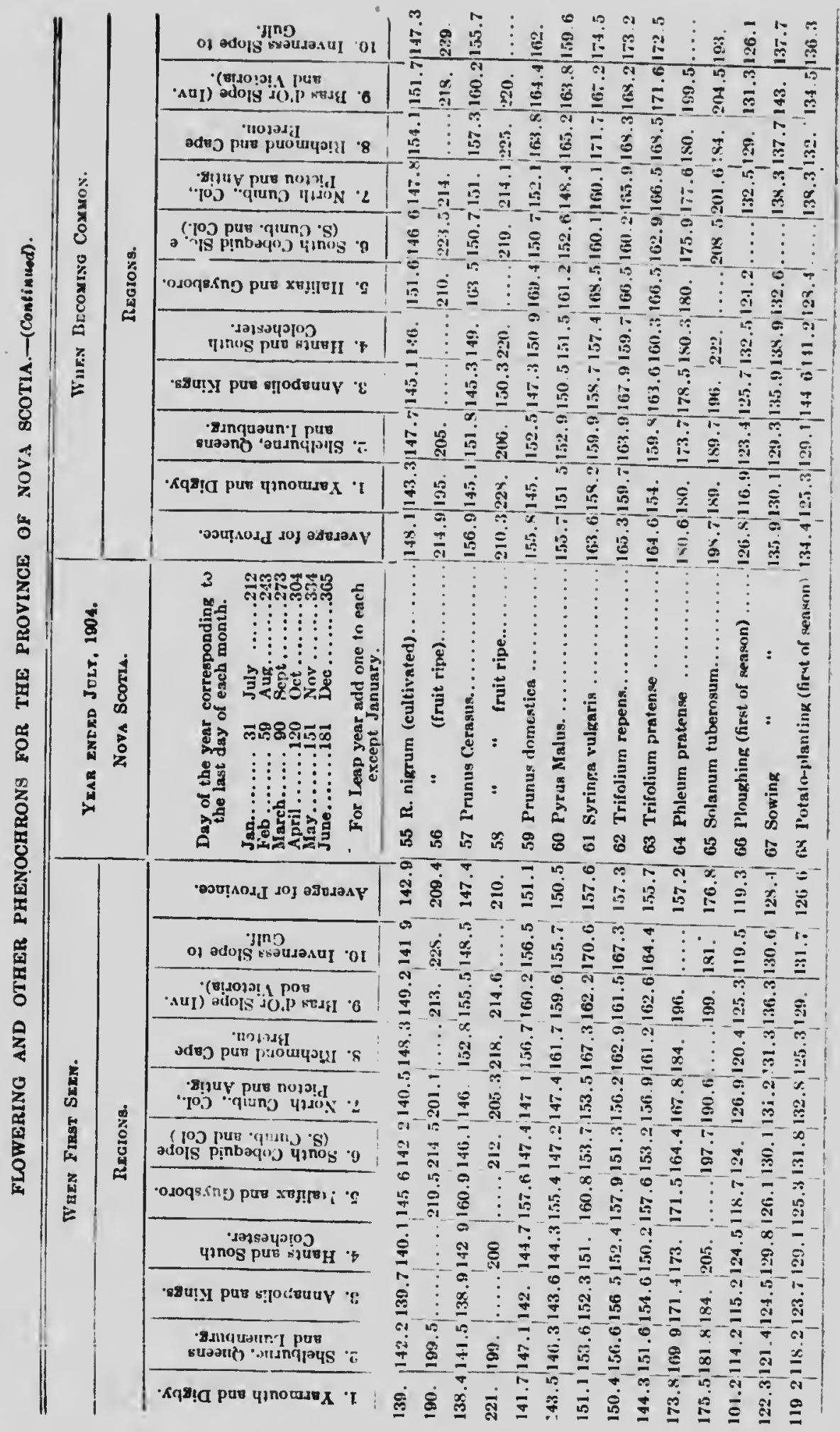




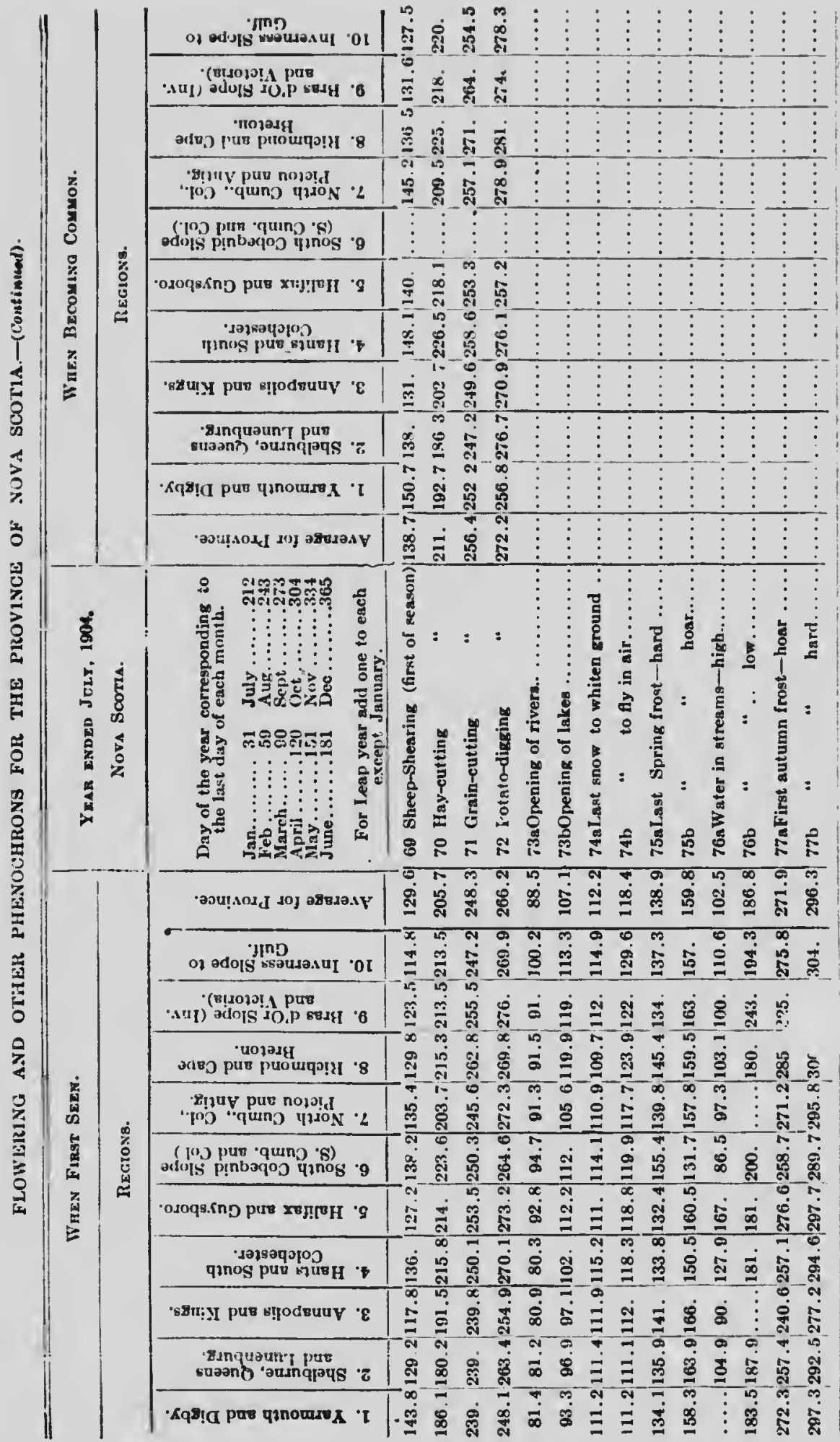




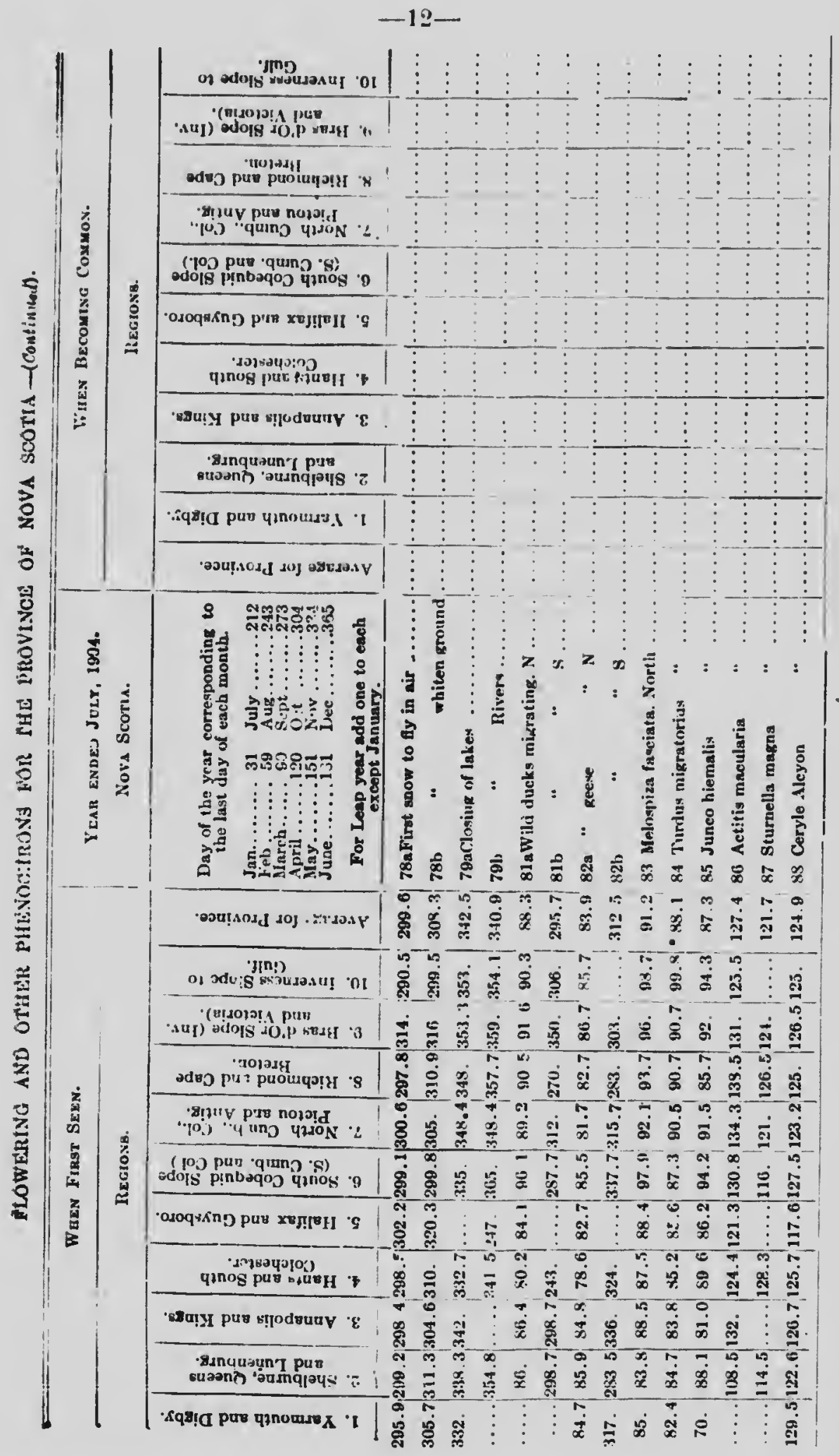




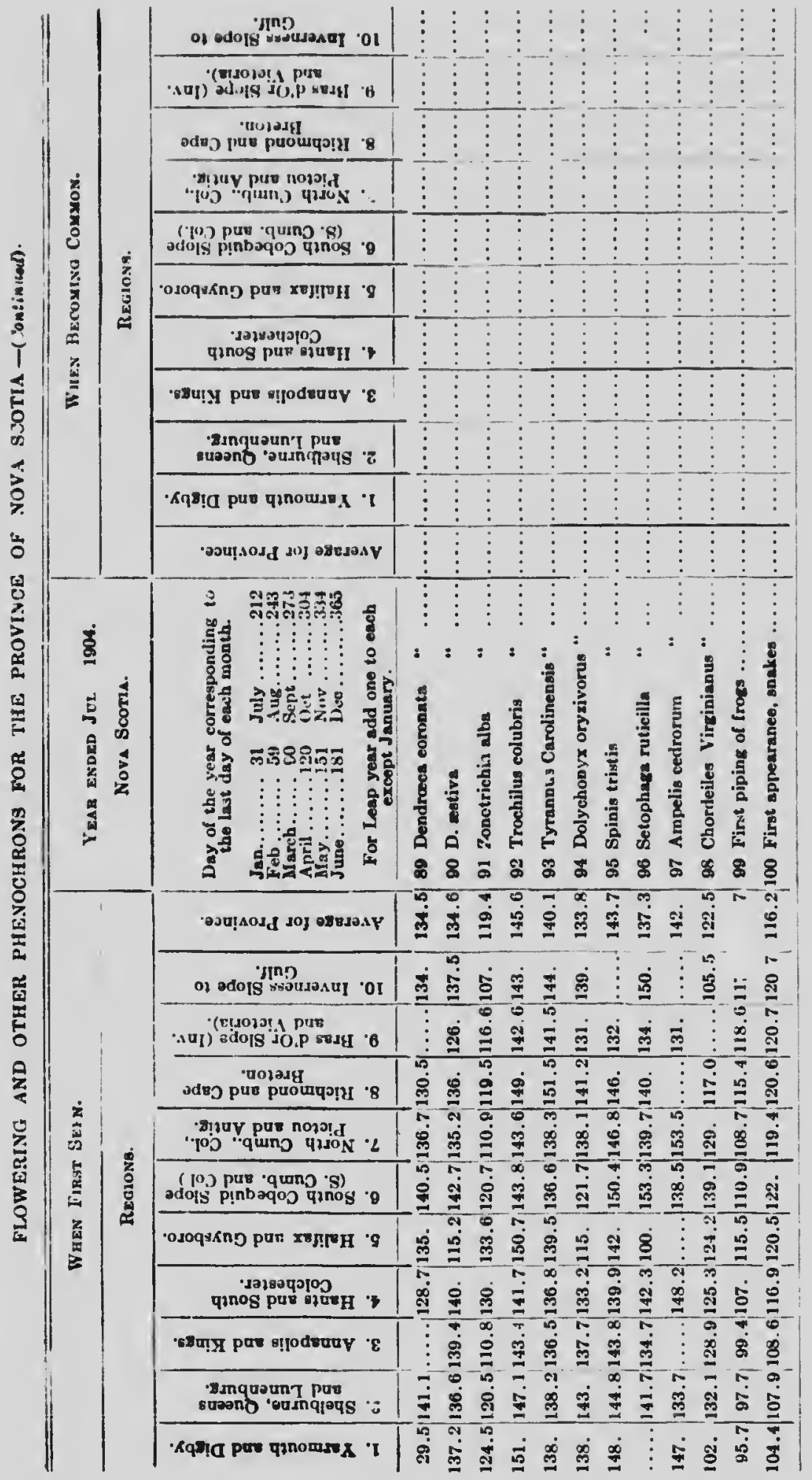




\section{$-11-$}

THUNDFRSTOR.IS-PHENOLOGICAI, OUSHRVATIONS, NOYA SCOTIA, IVU3.

The indiges inlicate the number of wtations trom which the Thundentorn.4 were reported on the day of the yeur specifiel.

Obagnvation Station.

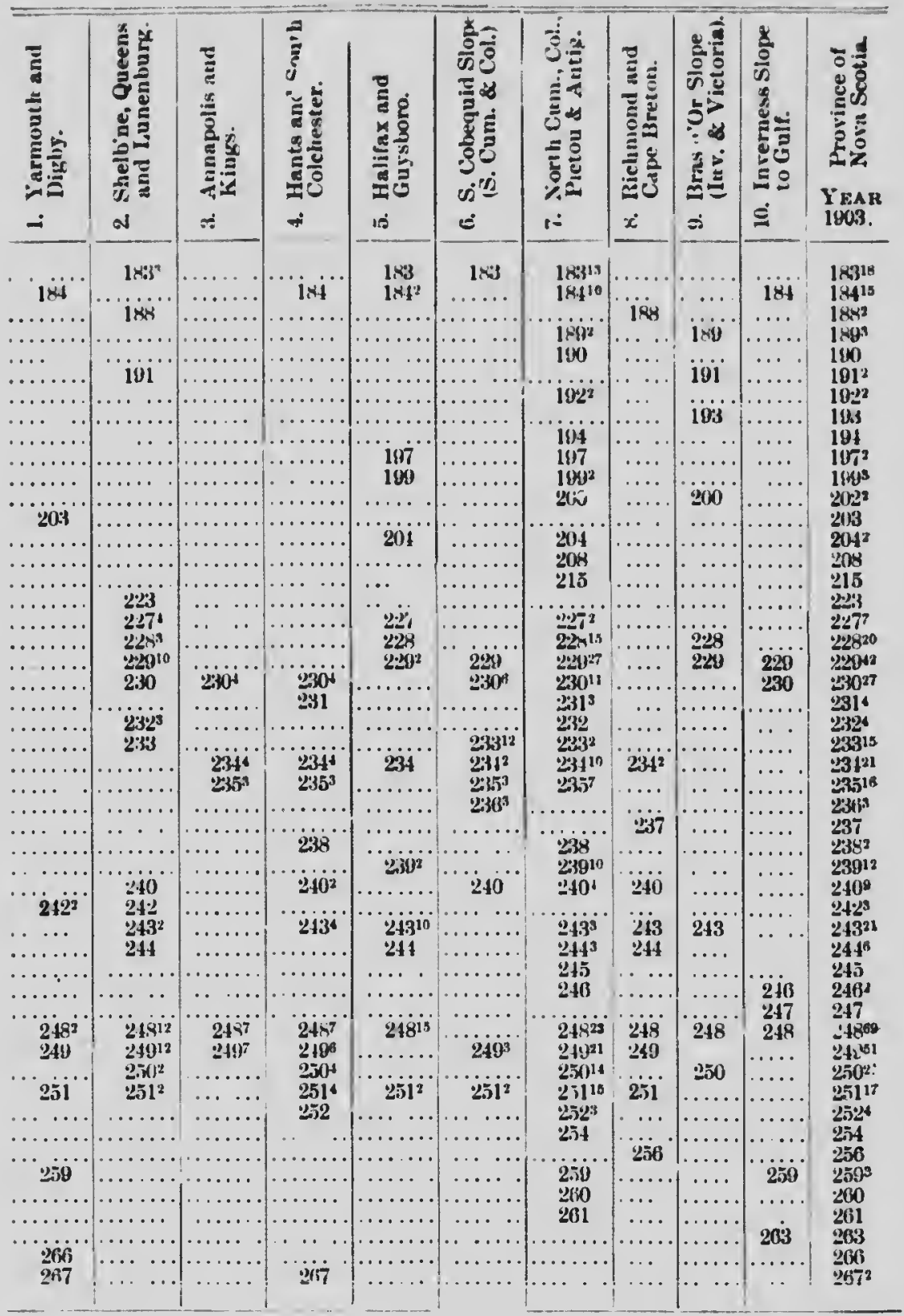


THUNDEISTORNS-PHENOLOGICAL OBSERVATIONS, NOVA SCULIA, IWA

The indices findicate the suubler of ntations from which the Thunderstorns were repoitiel on the day of the pear spectled.

OHнEหvation Stations.

\begin{tabular}{|c|c|c|c|c|c|c|c|c|c|c|}
\hline 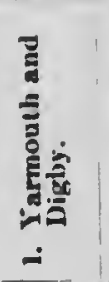 & 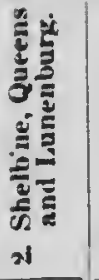 & 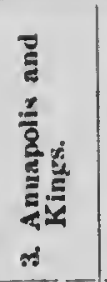 & 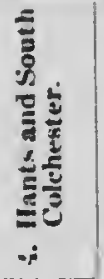 & 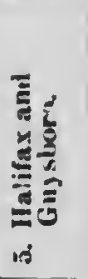 & 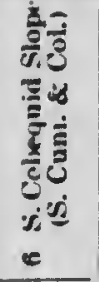 & 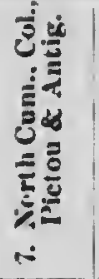 & 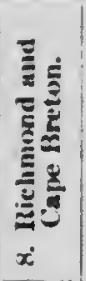 & 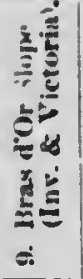 & 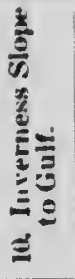 & 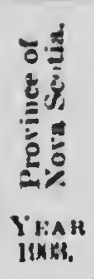 \\
\hline 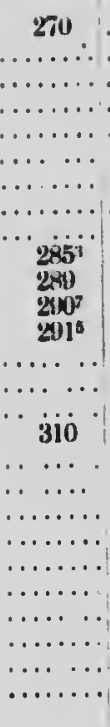 & 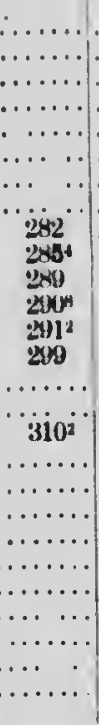 & $\begin{array}{c}\cdots \\
\cdots \\
\cdots \\
\cdots \\
\cdots\end{array}$ & $\begin{array}{l}\text { 2ivo } \\
\text { 2ingz }\end{array}$ & 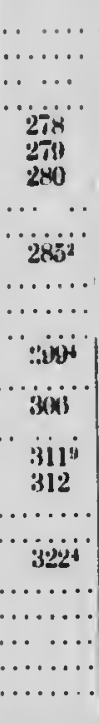 & $(9)^{2}$ & $\begin{array}{l}311^{8} \\
312^{4} \\
314 \\
3321 \\
322^{20} \\
323 \\
324 \\
324 \\
341^{2}\end{array}$ & $\begin{array}{c}311 \\
312 z \\
302 \\
3212 \\
32.2 \\
\ldots \ldots \\
\ldots \ldots \\
\ldots \ldots\end{array}$ & $\begin{array}{c}322 \\
\cdots \cdots \\
\cdots \\
\cdots \\
\cdots \cdots \\
\cdots \cdots \\
\cdots\end{array}$ & 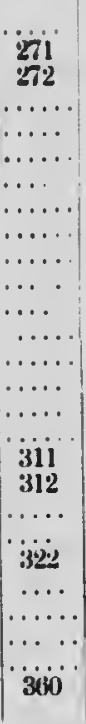 & 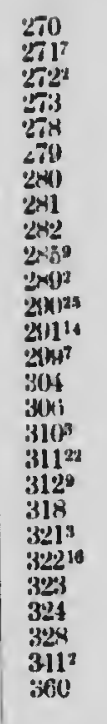 \\
\hline
\end{tabular}

YEAR 1904.

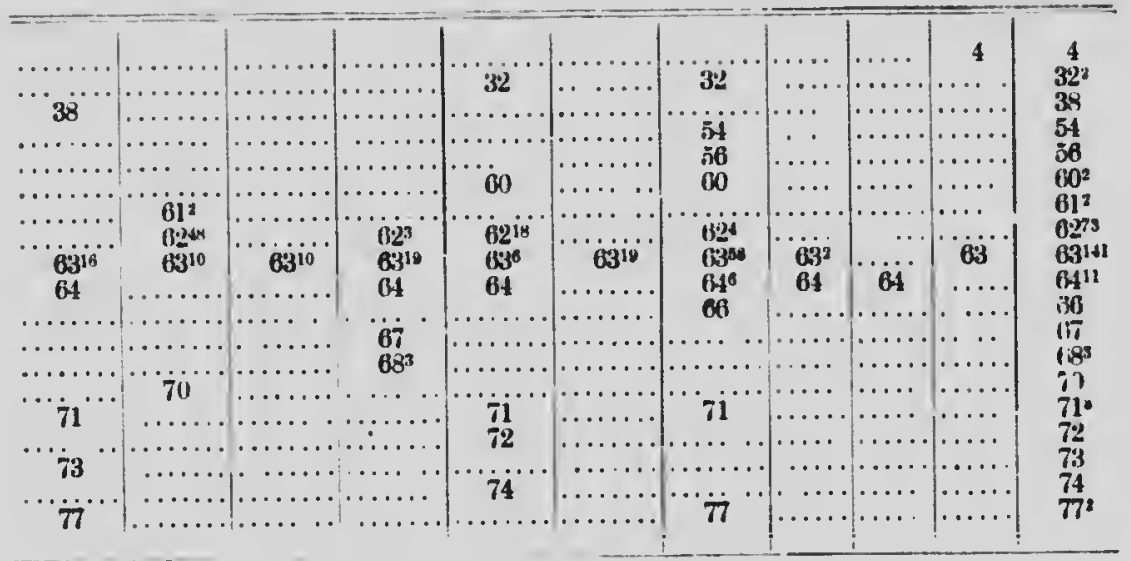




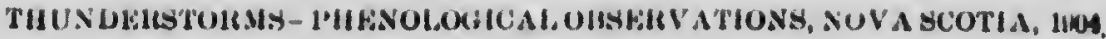

The fulicen indlente the number of etutions froun which the Thundentorms were reportol ou the day of the yent maseilled.

()ianhVATION STATHN.

\begin{tabular}{|c|c|c|c|c|c|c|c|c|c|c|}
\hline 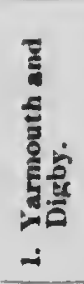 & 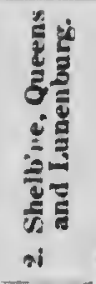 & 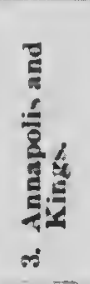 & 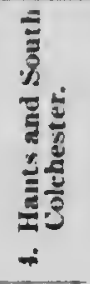 & 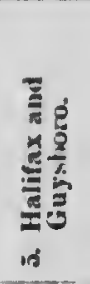 & 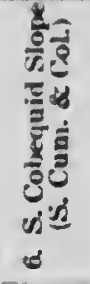 & 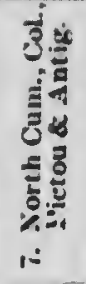 & 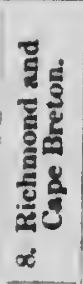 & 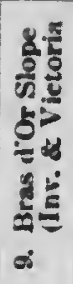 & 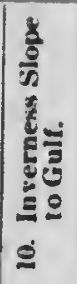 & 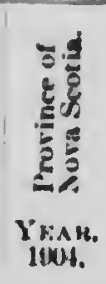 \\
\hline \multirow{5}{*}{ k) } & $=$ & & & 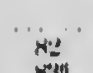 & 81 & & 81 & & & 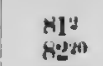 \\
\hline & $x_{3}$ & & & $x^{\prime \prime \prime}$ & . & $N$ & ... & & & $\begin{array}{l}F_{j}^{\prime} 13 \\
x_{\gamma^{\prime 2}}\end{array}$ \\
\hline & & & & & 42 & II! & $\ldots$ & . . . & 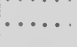 & U1 \\
\hline & 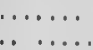 & (4:3: & & & & 44 & & $\cdots$ & $\ldots$ & 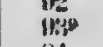 \\
\hline & & & & & & & & "150" & $\ldots$ & $\begin{array}{l}94 \\
116\end{array}$ \\
\hline \multirow{16}{*}{$\begin{array}{l}1022^{\circ} \\
10: 34 \\
104\end{array}$} & 10117 & 1014 & ivi & & & io1 ${ }^{\circ}$ & & ini & 101 & $\begin{array}{c}1 r^{2} \\
101^{26}\end{array}$ \\
\hline & 103 & $10 x^{2}$ & 102 & $10 ;$ & $1002 \sqrt{3}$ & $\begin{array}{l}102178 \\
10 ; 33^{2}\end{array}$ & 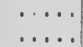 & 103 & 1063 & 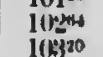 \\
\hline & & & & & & 1167 & ! & 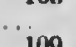 & & $\begin{array}{l}10370 \\
104\end{array}$ \\
\hline & 11 & & & & iiivi" & & .000 & 100 & $\cdots$ & $\begin{array}{l}\text { logen } \\
110^{*}\end{array}$ \\
\hline & 111 & & & & & $11 \%$ & ... & $\cdots$ & $\ldots$ & 111 \\
\hline & ... & $\ldots$ & 114 & & & & $\ldots . .$. & $\therefore$. & & $\begin{array}{l}112 \\
114\end{array}$ \\
\hline & & & & & & iiio' & $\ldots$ & & 117 & 117 \\
\hline & & $\mathrm{i} 21^{\circ}$ & 120 & $1: 0$ & 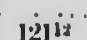 & $1: 1:)^{y}$ & $1: 0$ & $120^{\circ}$ & $120^{\circ}$ & $1 \%$ \\
\hline & & & & $i \geq 2$ & & $12: 25$ & . & …. & $\ldots$ & 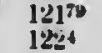 \\
\hline & 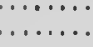 & & & 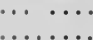 & 124 & 122,13 & & & & $\begin{array}{l}125 \\
123\end{array}$ \\
\hline & & & & 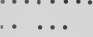 & $\ldots$ & 125 & & $\cdots$ & ... & $1: 44^{13}$ \\
\hline & & & 126 & & 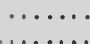 & $1: 0$ & & iipg & 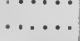 & $1: f^{2}$ \\
\hline & & & & & 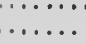 & & & & 120 & $\begin{array}{l}12 y^{3} \\
1: 29\end{array}$ \\
\hline & & $\cdots$ & iist" & $1:(x)$ & & 1349 & 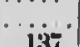 & . & $\ldots$ & $\begin{array}{l}130= \\
130\end{array}$ \\
\hline & & & $13: 4$ & i.3ख & & & 101 & & & $\begin{array}{l}1378 \\
133^{2}\end{array}$ \\
\hline & & & 141 & $\ldots$ & & $\begin{array}{l}140 \\
1+1^{13}\end{array}$ & $\because$ & $\cdots$ & $\ldots$ & 140 \\
\hline \multirow{7}{*}{$\begin{array}{l}145^{\circ} \\
140^{\circ}\end{array}$} & $145^{3}$ & & 1054 & & & & $\cdots$ & $144^{3}$ & iijit & 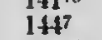 \\
\hline & 141 & & 100 & $\begin{array}{l}140 \\
146^{7}\end{array}$ & . & 146 & 146 & & 145 & $45^{16}$ \\
\hline & 1172 & $147^{3}$ & & 1477 & & 147 & $147^{8}$ & $147^{3}$ & & $\begin{array}{l}1407 \\
147^{28}\end{array}$ \\
\hline & $148^{\circ}$ & & & & $11 \mathrm{~N}^{2}$ & $144^{3}$ & 14812 & & $148^{5}$ & $148^{\circ}$ \\
\hline & 100 & & & & & & $140^{3}$ & 149 & & $149^{4}$ \\
\hline & & & & & & $1.51^{2}$ & $\ldots$ & 151 & 151 & 1514 \\
\hline & & & iojo & 104 & 101 & $\because 3$ & $105^{2}$ & & & $\begin{array}{l}15+1^{3} \\
153^{4}\end{array}$ \\
\hline \multirow{4}{*}{$\begin{array}{l}150 \\
157 \\
158 \\
151\end{array}$} & 1501 & & 156 & & & & & & . & $150^{3}$ \\
\hline & & & & & & i58 & 158 & & & $\begin{array}{l}157^{\circ} \\
158^{2}\end{array}$ \\
\hline & & & & & & & $\ldots$ & & $\cdots$ & 161 \\
\hline & & & & & & 108 & & & & 162 \\
\hline
\end{tabular}




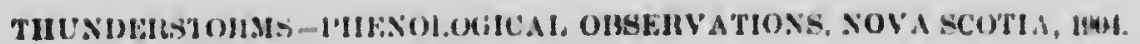

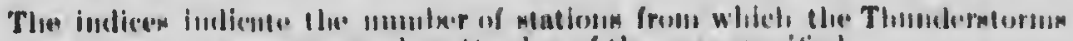

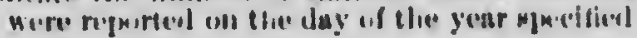

OHakivation Stations.

\begin{tabular}{|c|c|c|c|c|c|c|c|c|c|c|}
\hline 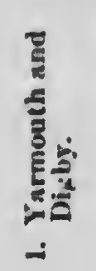 & 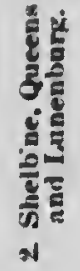 & 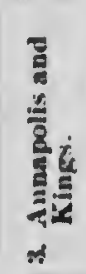 & 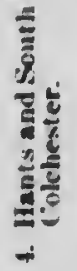 & 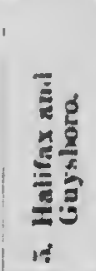 & 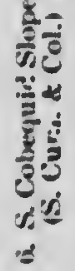 & 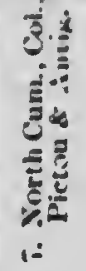 & 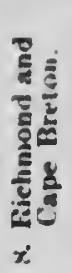 & 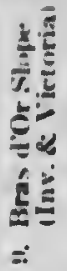 & 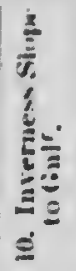 & 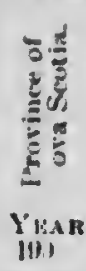 \\
\hline \multirow{4}{*}{$\begin{array}{l}\ldots \ldots \ldots \\
\ldots \ldots \ldots \\
\ldots \\
\ldots \ldots \ldots\end{array}$} & & & & 1034 & & $1+33^{2}$ & & & & \\
\hline & & & & & 1101 & & - & & & 1144 \\
\hline & & & laki & & & & & & $10 i^{2}$ & lilios \\
\hline & 115 & & $117^{4}$ & 16174 & & init & & & 1117 & lini \\
\hline jois & ins:" & & j(fial) & Ithes & IIISt & II: & & Iins & III & lithas: \\
\hline i11 & $10: 1$ & l(i) & Ithis & $\cdots$ & & (161) & & & 1(10) & lisen! \\
\hline $1: 1$ & & 171,3 & 1iㅔ: & .... & $1760^{\circ}$ & $170=$ & 17()$^{2}$ & 170 & $17(t)$ & 17 irs \\
\hline$: 71$ & & $\ldots \ldots$ & $171^{2}$ & & & $171_{4}$ & & & ..... & 1717 \\
\hline $17: i^{\circ}$ & 17.511 & & 17is: & $173^{\circ}$ & 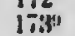 & 17.522 & & i77: & . & 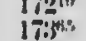 \\
\hline i= & & 174 & 174 & $17 y^{2}$ & $174^{1}$ & 17423 & . & 174 & 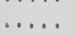 & $174^{4}$ \\
\hline & 17 & & & & & & & & & \\
\hline$\frac{170^{4}}{177^{4}}$ & 1734 & .. & lin & 170 & & & & & . & $1711 \cdot 2$ \\
\hline & $\ldots$ & ..... & 175 & איה & $17 n^{2}$ & & & & & $\begin{array}{l}7780 \\
178\end{array}$ \\
\hline 17 & & & & & & & & & $\cdots$ & 17 \\
\hline & & & 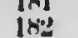 & & & & & & $\cdots$ & $181^{\circ}$ \\
\hline & & & & & & & & & & \\
\hline
\end{tabular}




\section{$-18-$}

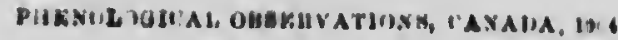

"Wurv I Iner Gexs,"

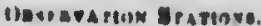

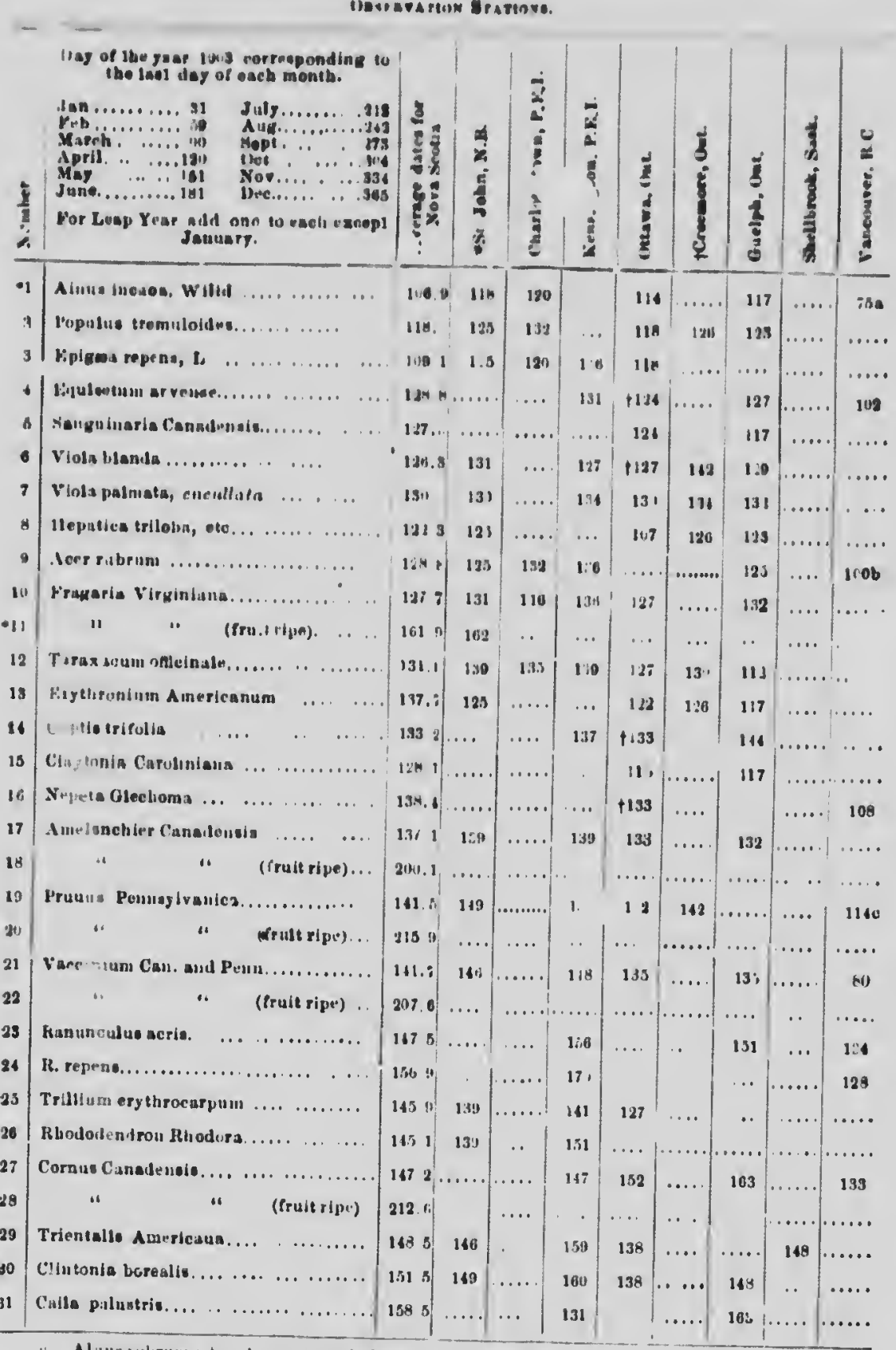

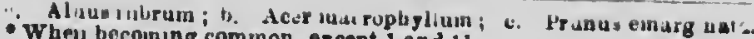
Whell beconina common, escent 1 and !1.

tWeu becoming common. 
PUKMOLOCLOLL ODHKATATIOK, OANADA, 1004

"Waun treer Dasm."

Oeceevazion Srationo.
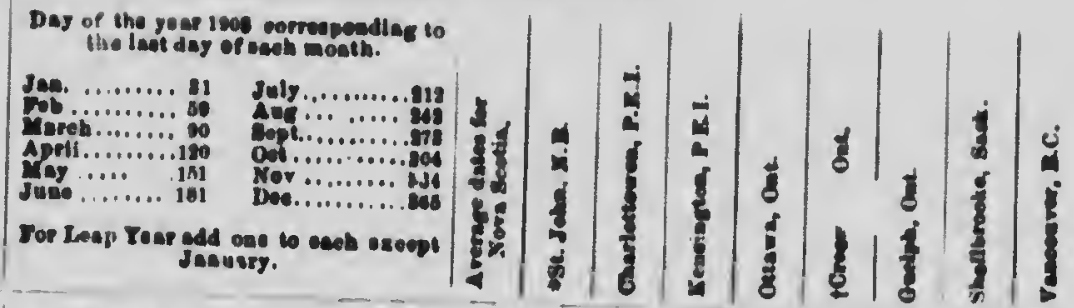

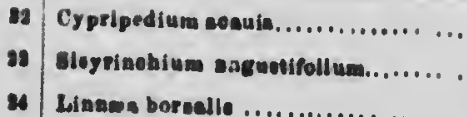

28 Kalmis glace...

w Kalmis aneroulfolin

7 Cratogue Onyeenthe

as

Crategun cocolates, to.

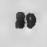

Irio veroicolor

41

48

Rubue strigonus.

"t $\quad$ (fruit ripe)

4 Ihinantius Orietergalif.
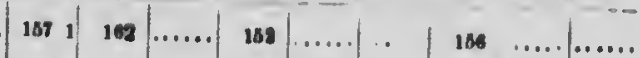
PHENOLOGICAL OHERVATHONS, CANADA, 101

"When Fuat Bers."

OBenevation Statova.

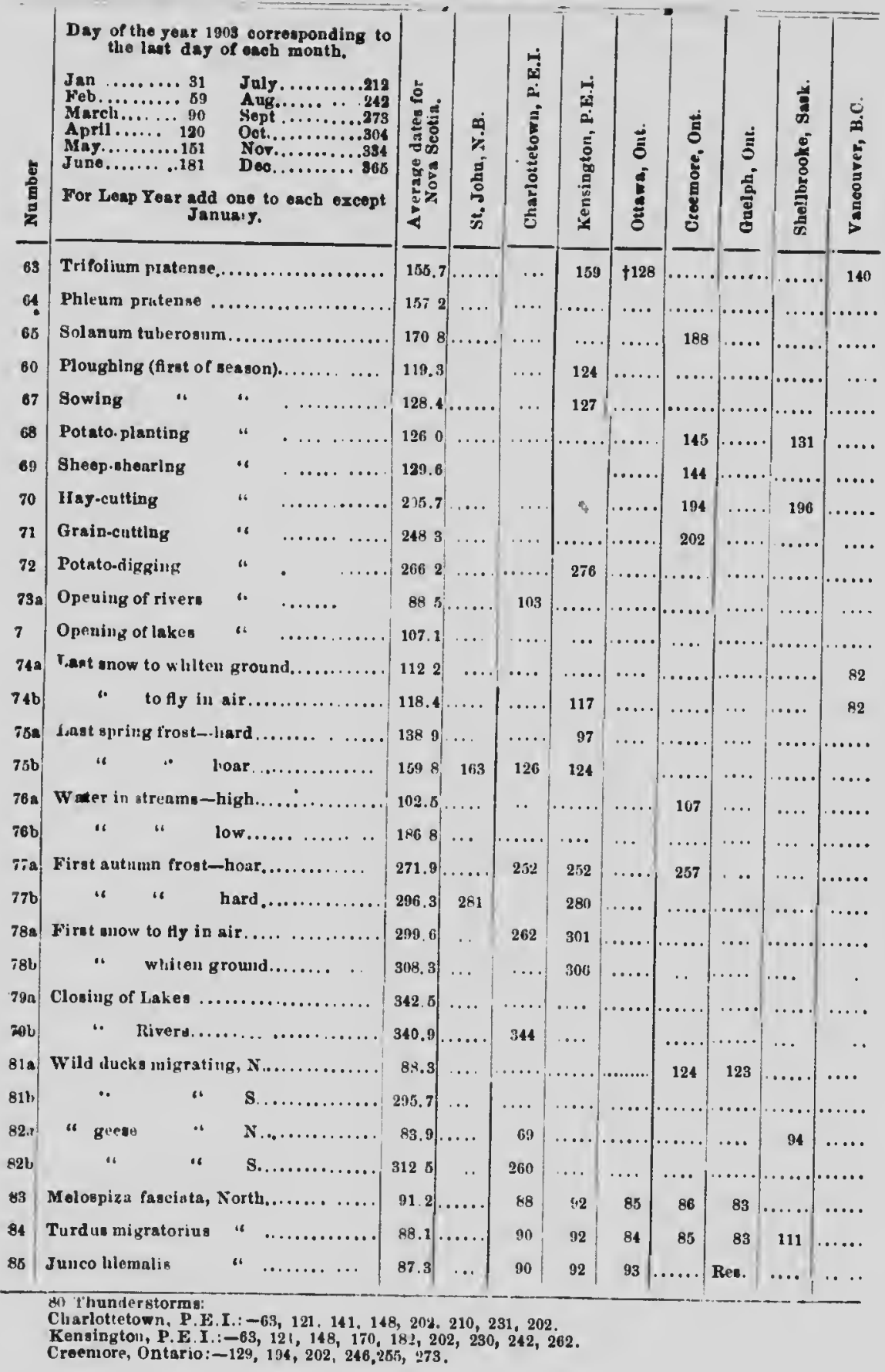


PHFinOLOGICAL OBSERVAmtons, CANAdA, 1904

"When Fiant Been."

Onarevation Statioxb.

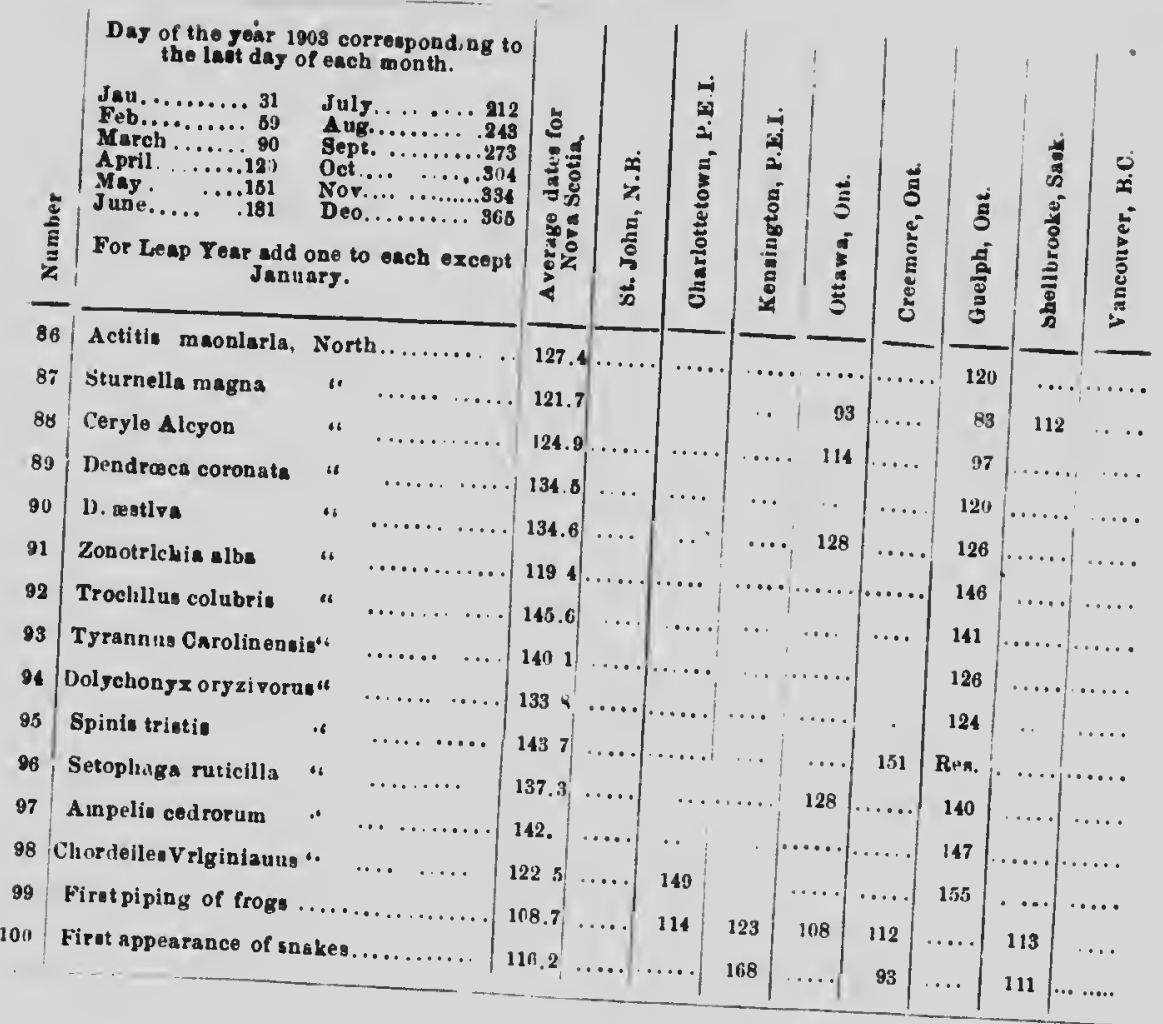




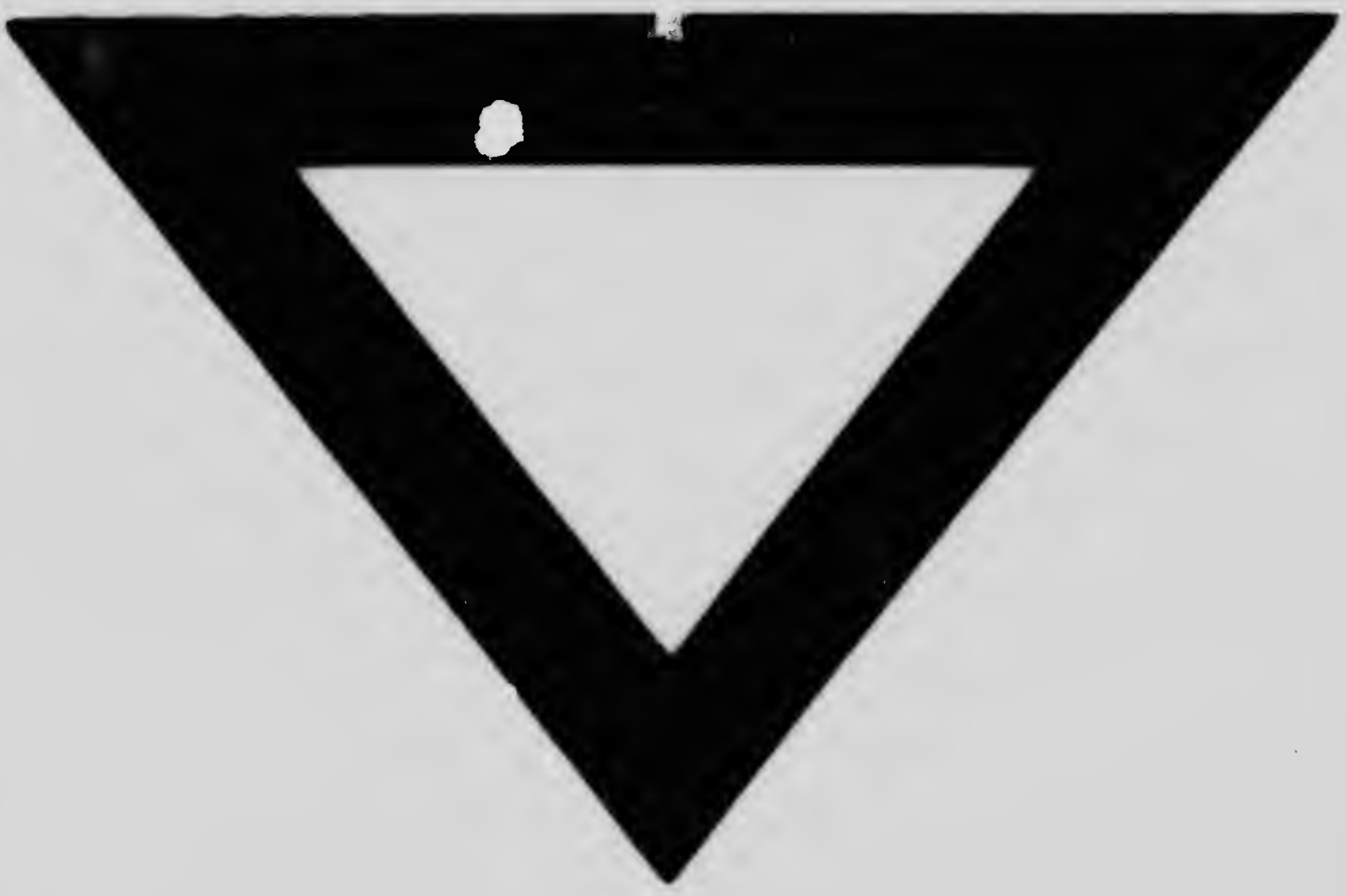

